\title{
Impact of Elevated Temperatures on Strength Properties and Microstructure of Calcium Sulfoaluminate Paste
}

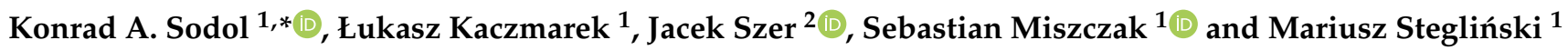 \\ 1 Faculty of Mechanical Enginnering, Institute of Materials Science and Engineering, Lodz University of \\ Technology, 90-924 Łódź, Poland; lukasz.kaczmarek@p.lodz.pl (Ł.K.); sebastian.miszczak@p.lodz.pl (S.M.); \\ mariusz.steglinski@p.lodz.pl (M.S.) \\ 2 Department of Building Physics and Building Materials, Faculty of Civil Engineering, Architecture and \\ Environment Engineering, Lodz University of Technology, 90-924 Łódź, Poland; jacek.szer@p.lodz.pl \\ * Correspondence: konrad.sodol@dokt.p.lodz.pl
}

Citation: Sodol, K.A.; Kaczmarek, Ł. Szer, J.; Miszczak, S.; Stegliński, M. Impact of Elevated Temperatures on Strength Properties and Microstructure of Calcium Sulfoaluminate Paste. Materials 2021, 14, 6751. https://doi.org/10.3390/ ma14226751

Academic Editor: Jaroslav Pokorný

Received: 8 October 2021

Accepted: 5 November 2021

Published: 9 November 202

Publisher's Note: MDPI stays neutral with regard to jurisdictional claims in published maps and institutional affiliations.

Copyright: (c) 2021 by the authors. Licensee MDPI, Basel, Switzerland. This article is an open access article distributed under the terms and conditions of the Creative Commons Attribution (CC BY) license (https:// creativecommons.org/licenses/by/ $4.0 /)$.
Abstract: This article is motivated by civil fire safety. Fire-prevention engineering demands a wide range of information about building materials including alternative cements, for instance CSAcement. Because of exposure of the cement-base material to a high temperature, its strength properties deteriorate due to dehydration connected with phase and microstructure changes. Previous research indicated that the main endothermic reaction of CSA-based composite, dehydration of ettringite, might be used as a cooling system for a metal structure during fire-load. This article examines visual assessment, microstructure, density, as well as flexural and compressive strength parameters of CSA-based composite after isothermal heating at temperatures from $23{ }^{\circ} \mathrm{C}$ to $800{ }^{\circ} \mathrm{C}$. The results of SEM/EDS investigations showed that the calcium sulfoaluminate paste may start partially resintering above $600{ }^{\circ} \mathrm{C}$. Mechanical tests revealed significant reduction of strength parameters but residual compressive strength was maintained in the whole temperature range e.g., $8 \mathrm{MPa}$ at $800{ }^{\circ} \mathrm{C}$. Additionally, visual assessment of the specimens indicated that it might be possible to predict the material temperature heating based on the specific surface color. These findings add to the evidence of general knowledge about CSA hydrates.

Keywords: calcium sulfoaluminate; high-temperature; microstructure; strength; green binder; cement

\section{Introduction}

One of the most popular binders in civil engineering is cement. Because of estimation that cement manufacturing release to the atmosphere $5-7 \%$ global $\mathrm{CO}_{2}$ per year [1] it is highly important to reduce carbon-dioxide emission in this branch of economy. The example of a binder with lower footprint than ordinary Portland cements (OPCs) is calcium sulfoaluminate (CSA) cement. This binder is generally considered as a green alternative to OPC [2]. Its $\mathrm{CO}_{2}$ emission is reduced because of the lower temperature needed for the sintering process and energy for klinker milling during production in comparison to OPC manufacturing [3]. Standard ASTM C-845-96 [4] describes expansive cements (CSA). The main hydrated calcium sulfoaluminate phases are ettringite, monosulfite and alumina hydroxide [5]. Previous research indicated that hydration of ettringite caused tensile stress in materials because of high expansiveness of this phase [6]. Because of ye'elemite and gypsum hydration, highly-compressive strength cement stone is created, where compressive strength may be higher than in OPC [7]. Strength and performance parameters are very important for special civil projects applications, therefore CSA cements should also be tested in extreme conditions, such as very low or high temperatures, to ensure safety in all situations.

In general, high temperature exposure causes a series of physio-chemical changes in cementitious materials. Previous issues show that strength parameters decrease, the spalling effect may destroy material, pores rise and material loses water during the dehydration 
of phases [8]. The influence of high temperature on cement composites was the subject of experimental and theoretical extensive studies [9-14]. Most of them considered Portland cement-based materials. Thermo-hydro-mechanical consideration with temperature influences on CSA-based material have not been fully analysed. The findings describing phase transition of CSA materials during high temperature are presented in Table 1.

Table 1. Calcium Sulfo-Aluminate (CSA) Phase Decomposition $[15,16]$.

\begin{tabular}{cc}
\hline Temperature Exposure & Phase Decompositions in CSA Concrete \\
\hline from $90{ }^{\circ} \mathrm{C}$ & Ettringite dehydration and decomposition to monosulfite \\
from $150{ }^{\circ} \mathrm{C}$ & and calcium sulfate \\
$200-300{ }^{\circ} \mathrm{C}$ & Partially monosulfite dehydration \\
from $450^{\circ} \mathrm{C}$ & Alumina trihydrate dehydroxylation \\
\end{tabular}

Sodol et al. [17] showed that CSA-based, OPC-CSA-based composite had a higher endothermic sum of phase transition during high temperature than OPC and paste. They pointed out that better understanding of an endothermic reaction is important from a cooling mechanism point of view. During fire-temperature exposure, a cooling mechanism might protect metal structures as infills or covers. The experimental data indicate that the cooling mechanism of CSA-based material is more efficient than that of OPC during $30 \mathrm{~min}$ and $60 \mathrm{~min}$. The previous research shows that Portland cement material is heat resistant up to $400{ }^{\circ} \mathrm{C}$ [18], while CSA is heat resistant up to $150{ }^{\circ} \mathrm{C}$ [19]. Due to reversible ettringite phase transition of CSA-based material, it is possible to use it as heat storage system [20].

Because of fire safety engineering considerations, it is necessary to expand the data base about high-temperature influence on alternative binders, for example CSA-based materials. This paper refers to CSA paste behavior during exposure to elevated temperature of $800^{\circ} \mathrm{C}$. It shows the strength parameters and density as a temperature function. The findings extend the current stage of knowledge about microstructure of CSA paste loaded by temperature and describes principal visual assessment rules of colors after high-temperature exposure.

\section{Materials and Methods}

\subsection{Specimen Preparation}

Specimens were prepared by mixing water from a water framework with CSA cement, (series AliCEM Green), where the main binder was a mixture of CSA cement clinker and gypsum in 4:1 ratio (chemical composition is showed in Table 2).

Table 2. Chemical Composition of CSA Cement.

\begin{tabular}{cccccccccc}
\hline Composition & $\mathrm{SiO}_{2}$ & $\mathrm{Al}_{2} \mathrm{O}_{3}$ & $\mathrm{CaO}$ & $\mathrm{Fe}_{2} \mathrm{O}_{3}$ & $\mathrm{MgO}$ & $\mathrm{K}_{2} \mathrm{O}$ & $\mathrm{Na}_{2} \mathrm{O}$ & $\mathrm{SO}_{3}$ & $\mathrm{TiO}_{2}$ \\
\hline wt. $\%$ & 6.89 & 23.74 & 43.06 & 1.11 & 2.70 & 0.68 & 1.01 & 20.37 & 0.44 \\
\hline
\end{tabular}

The cement/water ratio was 0.5. The temperature of water used in mixture was $9-10^{\circ} \mathrm{C}$. We created 24 specimens in $40 \mathrm{~mm} \times 40 \mathrm{~mm} \times 160 \mathrm{~mm}$ forms, according to the PN-85/B-04500 standard [21]. In the first step, ingredients were combined and mixed by using electrical stirrer. Then, liquid cement paste was poured to tripartite forms which were subjected to vibration. After removing excess paste, the specimens were secured by wet gauze and filter paper to reduce the water evaporation and left for $24 \mathrm{~h}$. Following this, specimens were demolded and treated in a 100\% humidity environment (wet conditioning) for 6 days. Then, the samples were treated in $65 \pm 5 \%$ humidity environment for 21 days (air-wet conditioning). Finally, 28-day samples were heat-treated in an electrical atmosphere oven (NEOTherm, Zakład Elektromechaniczny, Wrocław, Polska). The heat-treatment regime, including: heating rate. isothermal heating, cooling rate, number of specimens and 
their shape was maintained in accordance with previous research [22-26]. The parameters of heat-treatment are presented in Table 3.

Table 3. Parameters of Specimens' Heat Treatment.

\begin{tabular}{|c|c|c|c|c|c|}
\hline $\begin{array}{c}\text { Heat- } \\
\text { Treatment } \\
\text { Temperature }\end{array}$ & $\begin{array}{l}\text { Heating } \\
\text { Rate }\end{array}$ & $\begin{array}{c}\text { Isothermal } \\
\text { Heating }\end{array}$ & $\begin{array}{c}\text { Cooling } \\
\text { Rate }\end{array}$ & $\begin{array}{l}\text { Quantity of } \\
\text { Specimens for } \\
\text { Each Point }\end{array}$ & $\begin{array}{l}\text { Specimen } \\
\text { Dimension }\end{array}$ \\
\hline $\begin{array}{c}105,150,200 \\
300,400,600, \\
800{ }^{\circ} \mathrm{C}\end{array}$ & $5^{\circ} \mathrm{C} / \mathrm{min}$ & $2 \mathrm{~h}$ & $\begin{array}{c}\text { with } \\
\text { furnace }\end{array}$ & 3 & $40 \mathrm{~mm} \times 40 \mathrm{~mm} \times 160 \mathrm{~mm}$ \\
\hline
\end{tabular}

After heat treatment. specimens were weighted at electronic weight measure device (Vesta EKS01, Nikyo Duchnice, Poland) and photographed in order to describe color and external skin structure. Then. strength of the specimens was tested. Finally, macrostructures were observed using JOEL JSM-LV SEM (JOEL Ltd., Tokyo, Japan).

\subsection{Strength Parameters}

The flexural and compressive strength parameters were measured on strength test machine (Static press C089 PN606, Matest S.p.A., Arcore, Italy) in accordance with PN-EN 1015-11:2001 standard [21]: "Methods of test for mortar for masonry. Determination of flexural and compressive strength of hardened mortar". Test value was measured by using cold method [27]. The flexural strength analysis was conducted for three specimens from each temperature point. After that, for five half-part of the specimens compressive strength was tested. One half part of each specimen was used for microstructure research.

\subsection{Microstructure}

Internal microstructure of prepared samples was assessed by scanning electron microscopy (SEM, JOEL Ltd., Tokyo, Japan). Specimens for observations were taken from fracture sample pieces. After sputtering with a thin layer of gold, the samples were observed using a JOEL JSM-LV SEM microscope (JOEL Ltd. Company, Tokyo, Japan) in back scattered electrons (BSE) mode at $25 \mathrm{kV}$ accelerating voltage.

\subsection{Density}

Density was determined from average weight of three samples measured in different temperature points using a weight device (VESTA EKS01, Nikyo, Duchnice, Poland) and calculated specimens volume.

\section{Results and Discussion}

\subsection{Visual Observation}

Heat-treated specimens were visually assessed in order to observe changes of color and appearance of cracks and/or pores. Images of assessed specimens are presented in Table 4 . The visual assessment was the first test performed after exposure at $105^{\circ} \mathrm{C}, 150{ }^{\circ} \mathrm{C}$, $200{ }^{\circ} \mathrm{C}, 300{ }^{\circ} \mathrm{C}, 400{ }^{\circ} \mathrm{C}, 600^{\circ} \mathrm{C}$ and $800^{\circ} \mathrm{C}$. The main observed changes of material exposed to high temperature is color change and crack appearance. Observation shows that color did not change noticeably between $23^{\circ} \mathrm{C}$ and $400{ }^{\circ} \mathrm{C}$. The first cracks were observed above $200{ }^{\circ} \mathrm{C}$. The patterns on the surface were like the flat figure with 5-8 sides (examples are marked in Table 4: $200{ }^{\circ} \mathrm{C}$ heat-treatment). Because of temperature increasing to $300{ }^{\circ} \mathrm{C}$ cracks propagation increased by connecting the edges of previous cracks by transverse cracks. Above $400{ }^{\circ} \mathrm{C}$, registered changes show that thickness of existing cracks increased without increasing the amount of them. Significant changes were found at $600{ }^{\circ} \mathrm{C}$ color of specimens changed from natural beige to dark gray with black pieces. Furthermore, the number of cracks decreased. Above $800^{\circ} \mathrm{C}$, the color of the specimens changed again. from dark gray with black pieces to light gray. The size of the cracks did not increase, however, deformation of specimens was observed. 
Table 4. Comparison of Visual Results.

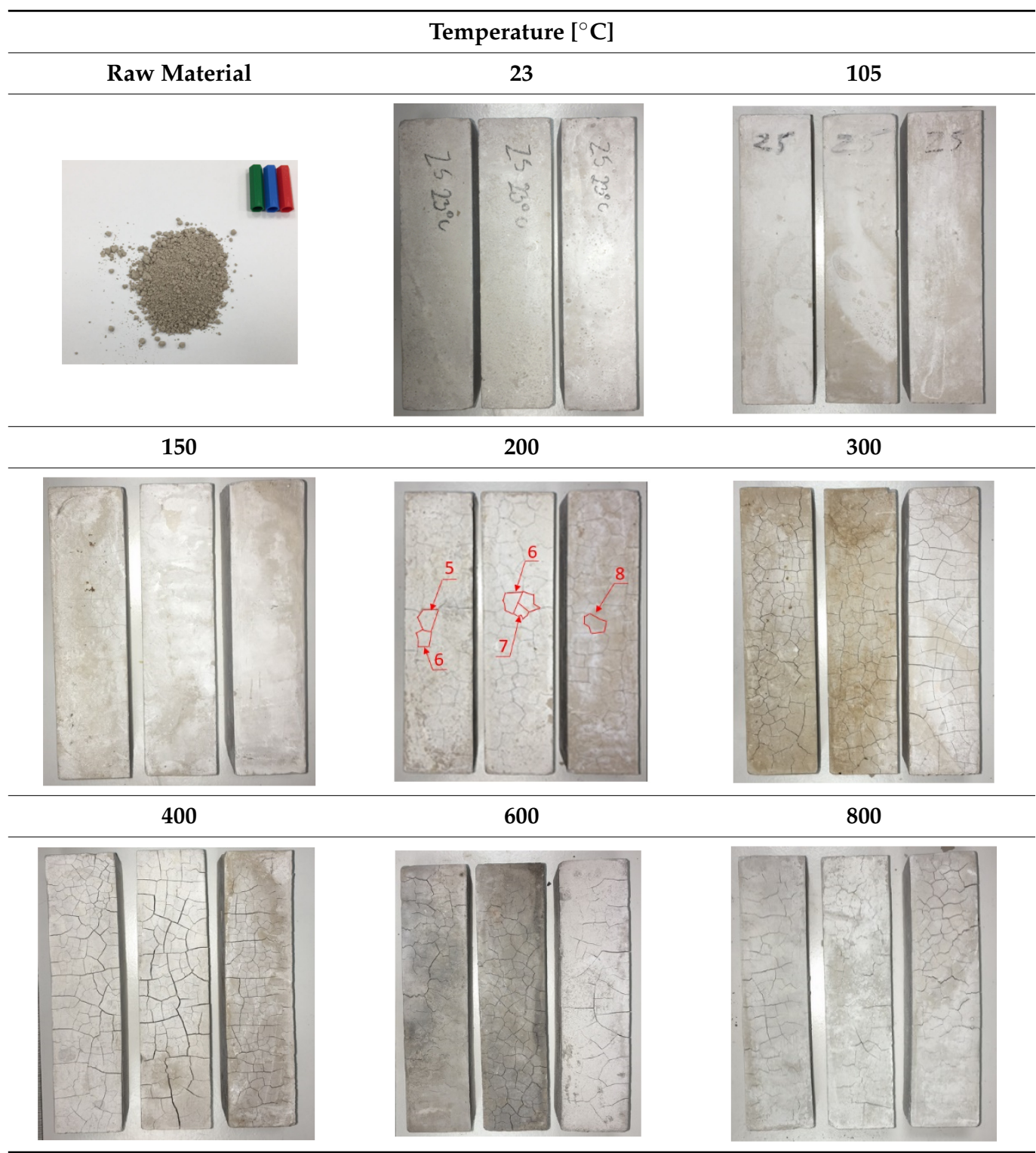

\subsection{Density}

Presented data below is motivated by determination the density of the material. The weight of samples was measured after each heating step. Figure 1 presents average density in each temperature point.

High-temperature exposure $\left(105-800{ }^{\circ} \mathrm{C}\right)$ caused removal of humidity and water in pores. as well as dehydration and dehydroxylation of present cement phase of the paste in different stages of temperature. Therefore, density of the material decreased gradually to each temperature level. In the following part, density should be understood as calculated density. It needs to be emphasized that changes in value will be discussed in accordance with initial value, which is shown in Table 5 . 


\section{Density behavior after temperature exposure}

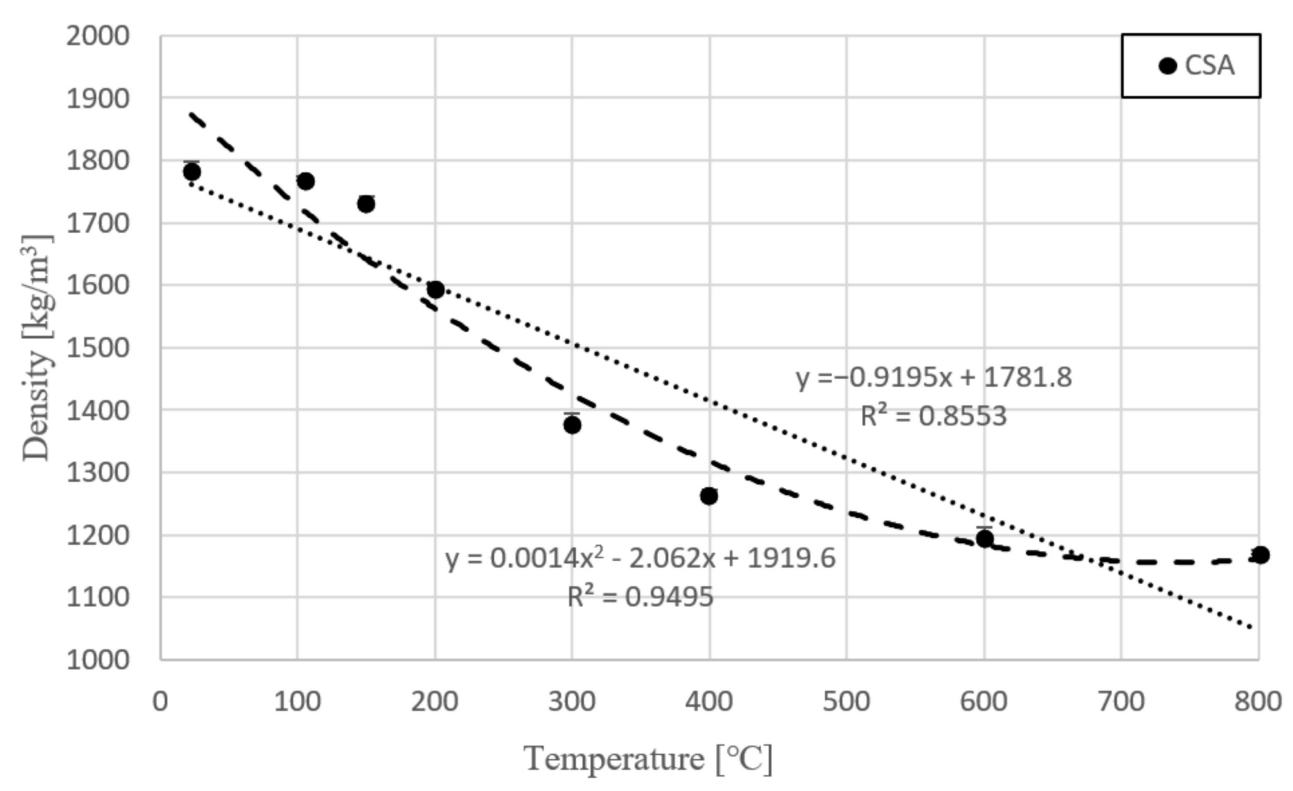

Figure 1. Density behavior after exposure at different temperatures.

Table 5. Change in Density of Heated Samples Relative to the Reference Sample.

\begin{tabular}{ccccccccc}
\hline Temperature $^{\circ} \mathbf{C}$ & $\mathbf{2 3}$ & $\mathbf{1 0 5}$ & $\mathbf{1 5 0}$ & $\mathbf{2 0 0}$ & $\mathbf{3 0 0}$ & $\mathbf{4 0 0}$ & $\mathbf{6 0 0}$ & $\mathbf{8 0 0}$ \\
\hline Density $\left[\mathrm{kg} / \mathrm{m}^{3}\right]$ & 1785.2 & 1768.2 & 1731.8 & 1593.8 & 1377.6 & 1264.3 & 1194 & 1169.3 \\
\hline Relative density & $100 \%$ & $99.1 \%$ & $97 \%$ & $89.3 \%$ & $77.2 \%$ & $70.8 \%$ & $66.9 \%$ & $65.5 \%$ \\
\hline
\end{tabular}

Density was $1785 \mathrm{~kg} / \mathrm{m}^{3}$ in green state $\left(23^{\circ} \mathrm{C}\right)$, above $105^{\circ} \mathrm{C}$ density decreased by less than $1 \%$. At $150{ }^{\circ} \mathrm{C}$, density decreased by $3 \%$ from the green state. The first significant change in density was measured at $200{ }^{\circ} \mathrm{C}$, where value dropped $10.7 \%$. Above $300{ }^{\circ} \mathrm{C}$, values sharply dropped around $22.8 \%$. After that, density dropped slightly to $70.8 \%$ initial value $\left(1264.6 \mathrm{~kg} / \mathrm{m}^{3}\right)$ at $400{ }^{\circ} \mathrm{C}$. Next, at $600{ }^{\circ} \mathrm{C}$, density fell to $1194 \mathrm{~kg} / \mathrm{m}^{3}$, which was $66.9 \%$ of the starting value. Finally, last temperature point, $800{ }^{\circ} \mathrm{C}$, shows that the value dropped to $65.5 \%$ of initial value $\left(1169.2 \mathrm{~kg} / \mathrm{m}^{3}\right)$.

For points presented in Figure 1, two different trend line equations have been established. First, the linear trend line is dedicated for simplified calculation, where correlation $R^{2}$ ratio was 0.85 . The equation of the characteristic trend line is presented below.

$$
\begin{gathered}
y=-0.9195 x+1781.8 \quad R^{2}=0.8553 \\
y=a x+b \\
b=1781.8 \wedge \rho_{23}{ }^{\circ} \mathrm{C}=1785.1=>b \approx \rho_{23}{ }^{\circ} \mathrm{C} \\
\rho_{\mathrm{T}}(\mathrm{T})=\rho_{23}{ }^{\circ} \mathrm{C}+0.92 \mathrm{~T}
\end{gathered}
$$

The presented trend line equation was modified from the special equation (Equation (1)) to general equation (Equation (3)). The second order line equation (Equation (4)) is dedicated to more complicated issues, where correlation $R^{2}$ ratio was 0.94 .

$$
y=0.0014 x^{2}-2.062 x+1919.6 \quad R^{2}=0.9495
$$




\subsection{Flexural and Compressive Strength}

Flexural strength values as a temperature function are presented in Figure 2. Figure 3 shows compressive strength as a temperature function. Percentage changes of strength parameters vs initial value are presented in Table 6.

\section{Flexural strength as a temperature function}

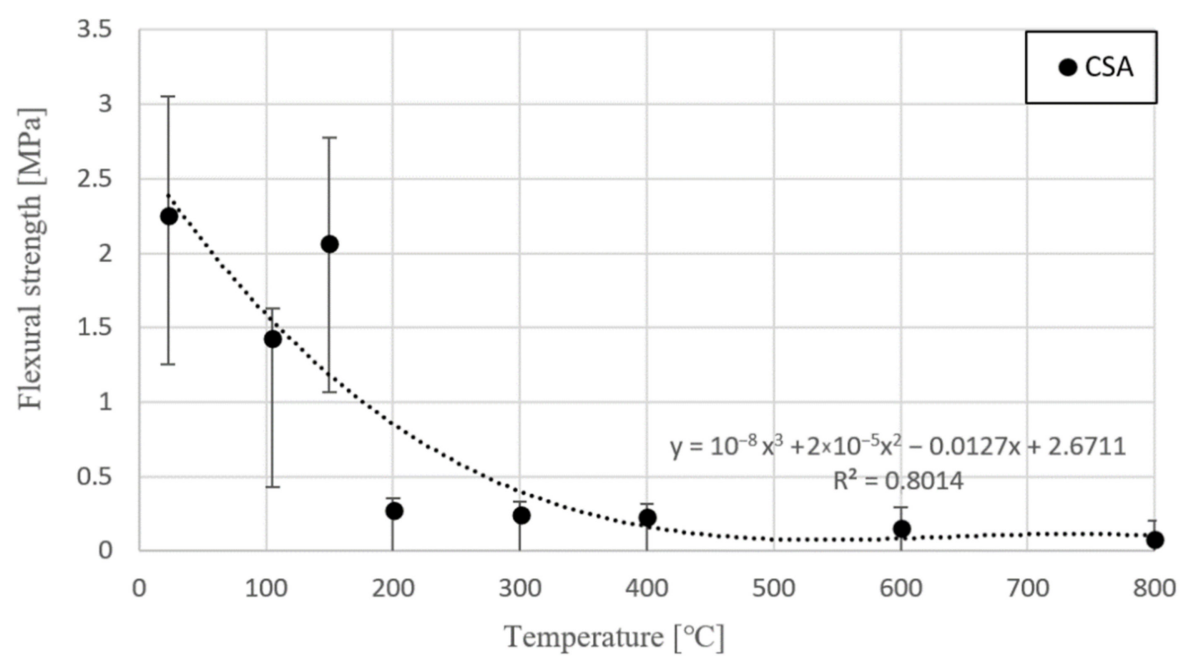

Figure 2. Flexural strength $[\mathrm{MPa}]$ in accordance with PN-EN 1015-11 as a temperature function.

\section{Compressive strength as a temperature function}

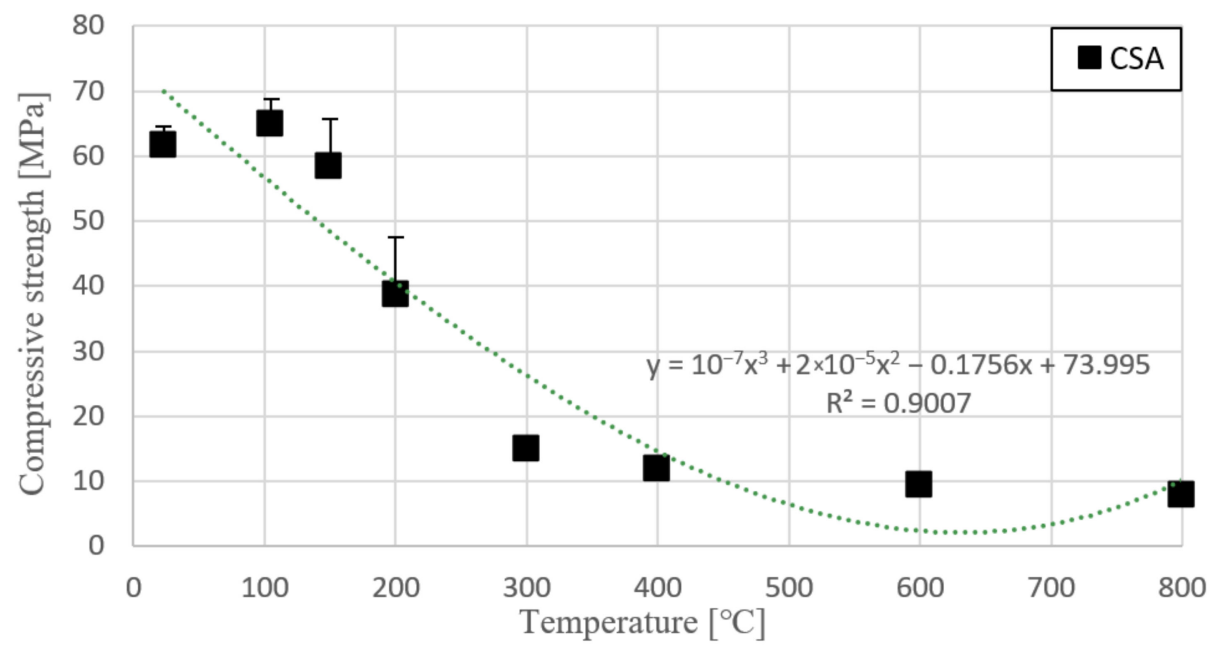

Figure 3. Compressive strength [MPa] in accordance with PN-EN 1015-11 as a temperature function.

Table 6. Strength Parameters Percentage [\%] Changes.

\begin{tabular}{ccccccccc}
\hline Temperature ${ }^{\circ} \mathbf{C}$ & $\mathbf{2 3}$ & $\mathbf{1 0 5}$ & $\mathbf{1 5 0}$ & $\mathbf{2 0 0}$ & $\mathbf{3 0 0}$ & $\mathbf{4 0 0}$ & $\mathbf{6 0 0}$ & $\mathbf{8 0 0}$ \\
\hline $\mathrm{f}_{\mathrm{f}}(\%)$ & 100 & 63.3 & 91.5 & 12.1 & 10.7 & 10.3 & 6.9 & 3.4 \\
\hline $\mathrm{f}_{\mathrm{c}}(\%)$ & 100 & 105.3 & 94.8 & 62.8 & 24.4 & 19.2 & 15.5 & 13.0 \\
\hline $\mathrm{f}_{\mathrm{f}}$-flexural strength; $\mathrm{f}_{\mathrm{c}}$-compressive strength.
\end{tabular}

Figure 2 shows temperature influence on flexural strength parameter of CSA paste. Firstly, flexural strength of green state of the CSA paste was $\mathrm{f}_{\mathrm{f} . \mathrm{CSA} .23^{\circ} \mathrm{C}}=2.5 \mathrm{MPA}$. Above $105{ }^{\circ} \mathrm{C}$, flexural strength dropped to $63.3 \%\left(\mathrm{f}_{\mathrm{f} . \mathrm{CSA} .105{ }^{\circ} \mathrm{C}}=1.43 \mathrm{MPa}\right)$ of initial value. Next,

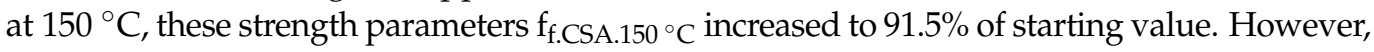


one value had significant influence on the average in this temperature point measurement,

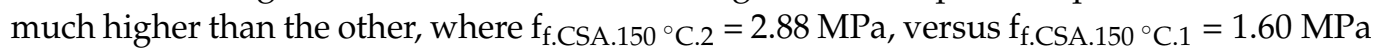
and $\mathrm{f}_{\mathrm{f} . \mathrm{CSA} .150{ }^{\circ} \mathrm{C} .3}=1.71 \mathrm{MPa}$. Excluding the highest value at $150{ }^{\circ} \mathrm{C}$, the average value might be $1.65 \mathrm{MPa}$, which is still s higher value than at $105^{\circ} \mathrm{C}$. Next, at $200^{\circ} \mathrm{C}$, flexural strength decreased to $12.1 \%$ of initial value. Between $200{ }^{\circ} \mathrm{C}$ and $400{ }^{\circ} \mathrm{C}$ the values were at a similar level. At $600{ }^{\circ} \mathrm{C}$, the value was at $6.9 \%$ of initial strength. Finally, at $800{ }^{\circ} \mathrm{C}$, the value was $\mathrm{f}_{\mathrm{f} . \mathrm{CSA} .800^{\circ} \mathrm{C}}=0.07 \mathrm{MPa}$, which may be considered negligible.

Figure 3 presents temperature influence on compressive strength parameter of CSA paste. Compressive strength of green state CSA paste was $\mathrm{f}_{\mathrm{c} . \mathrm{CSA} .23{ }^{\circ} \mathrm{C}}=61.7 \mathrm{MPa}$. Next, at $105{ }^{\circ} \mathrm{C}$ strength slightly increased to $105.3 \%$ initial value $\left(\mathrm{f}_{\mathrm{c} . \mathrm{CSA} .105{ }^{\circ} \mathrm{C}}=65 \mathrm{MPa}\right)$. Above $150{ }^{\circ} \mathrm{C}$ values dropped to $94.8 \%$. Between $150{ }^{\circ} \mathrm{C}$ and $200{ }^{\circ} \mathrm{C}$ compressive strength fell

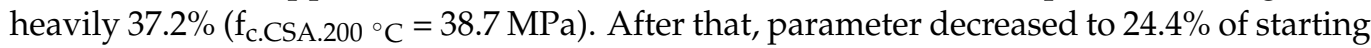
strength at $300^{\circ} \mathrm{C}$. Between $300^{\circ} \mathrm{C}$ and $600{ }^{\circ} \mathrm{C}$ values were at a similar level, not less than $15 \%$ of initial value. Finally, at $800{ }^{\circ} \mathrm{C}$, flexural strength was $\mathrm{f}_{\mathrm{c} . \mathrm{CSA} .800{ }^{\circ} \mathrm{C}}=8 \mathrm{MPa}$ which is $87 \%$ less than the green state of this material. Table 7 presents equations describing the trend lines as a temperature function and relation coefficient $R^{2}$.

Table 7. Equations of Strength Parameters' Trend Lines.

\begin{tabular}{cccc}
\hline Flexural strength & $\mathrm{f}_{\mathrm{f}}(\mathrm{T})=10^{-8} \mathrm{~T}^{3}+2 \times 10^{-5} \mathrm{~T}^{2}-0.0127 \mathrm{~T}+2.9711$ & $\mathrm{R}^{2}=0.8014$ & $(5)$ \\
\hline Compressive strength & $\mathrm{f}_{\mathrm{C}}(\mathrm{T})=10^{-7} \mathrm{~T}^{3}+2 \times 10^{-5} \mathrm{~T}^{2}-0.1756 \mathrm{~T}+73.995$ & $\mathrm{R}^{2}=0.9007$ & $(6)$ \\
\hline $\mathrm{f}_{\mathrm{f}}-$ flexural strength [MPa]; $\mathrm{f}_{\mathrm{c}}$-compressive strength [MPa].
\end{tabular}

Based on previous results of strength tests the flexural/compressive ratio as a temperature function is presented in Table 8 and Figure 4.

Table 8. Value of Flexural/Compressive (F-C) Ratio as Temperature Function.

\begin{tabular}{rcccccccc}
\hline Temp. $\left[{ }^{\circ} \mathrm{C}\right]$ & $\mathbf{2 3}$ & $\mathbf{1 0 5}$ & $\mathbf{1 5 0}$ & $\mathbf{2 0 0}$ & $\mathbf{3 0 0}$ & $\mathbf{4 0 0}$ & $\mathbf{6 0 0}$ & $\mathbf{8 0 0}$ \\
\hline F-C Ratio [] & 0.037 & 0.022 & 0.035 & 0.007 & 0.016 & 0.02 & 0.016 & 0.009 \\
\hline
\end{tabular}

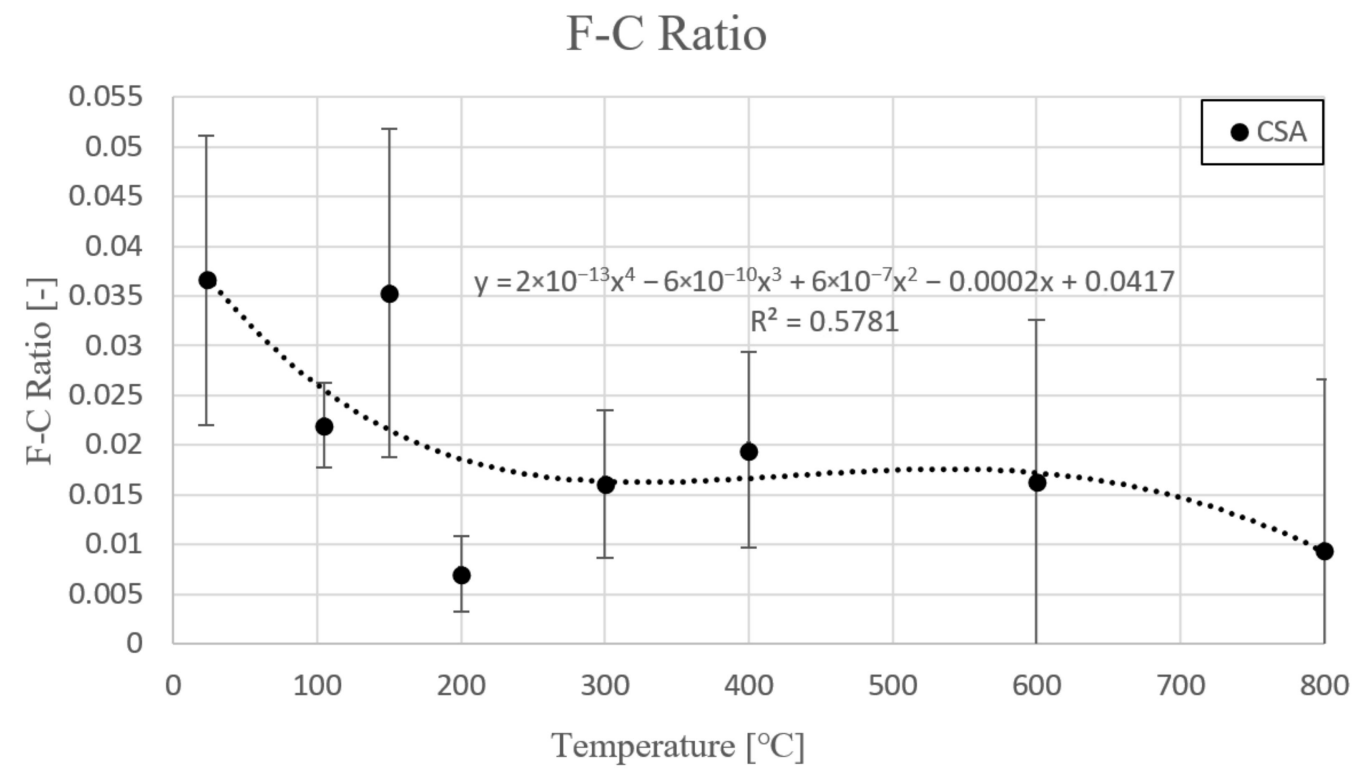

Figure 4. F-C ratio as a temperature function.

Generally, F-C Ratio as a temperature function fluctuated. Initial value was 0.037. Between $23{ }^{\circ} \mathrm{C}$ and $105^{\circ} \mathrm{C}$, the ratio decreased to 0.022 . After that, at $150{ }^{\circ} \mathrm{C}$ ratio rebuilt. Characteristic point, connected with fully dehydration of ettringite phase and partially dehydration of monosulfite, was at $200{ }^{\circ} \mathrm{C}$. Owing to substantial flexural strength decrease, 
the F-C ratio was significantly reduced. Next, between $200{ }^{\circ} \mathrm{C}$ and $400{ }^{\circ} \mathrm{C}$, the $\mathrm{F}-\mathrm{C}$ ratio increased, because of higher compressive strength drop in comparison to flexural strength. Prior to this, between $215^{\circ} \mathrm{C}$ and $270{ }^{\circ} \mathrm{C}$ aluminum hydroxide $\mathrm{Al}(\mathrm{OH})_{3}$ could be dehydroxylated, which released additional water to the structure. Between $400{ }^{\circ} \mathrm{C}$ and $800{ }^{\circ} \mathrm{C}$, a slight decrease of the $\mathrm{F}-\mathrm{C}$ ratio was observed. The trend line equation is presented with coefficient ratio $R^{2}$.

F-C Ratio(T) $=2 \times 10^{-13} \mathrm{~T}^{4}-6 \times 10^{-10} \mathrm{~T}^{3}-6 \times 10^{-7} \mathrm{~T}^{2}-0.0002 \mathrm{~T}+0.0417 \quad \mathrm{R}^{2}=0.5781$

\subsection{Microstructure}

The aim of the microstructure research was to present differences in material at different temperature points. Images of microstructures before and after heating at different temperatures are presented in Figures 5 and 6.
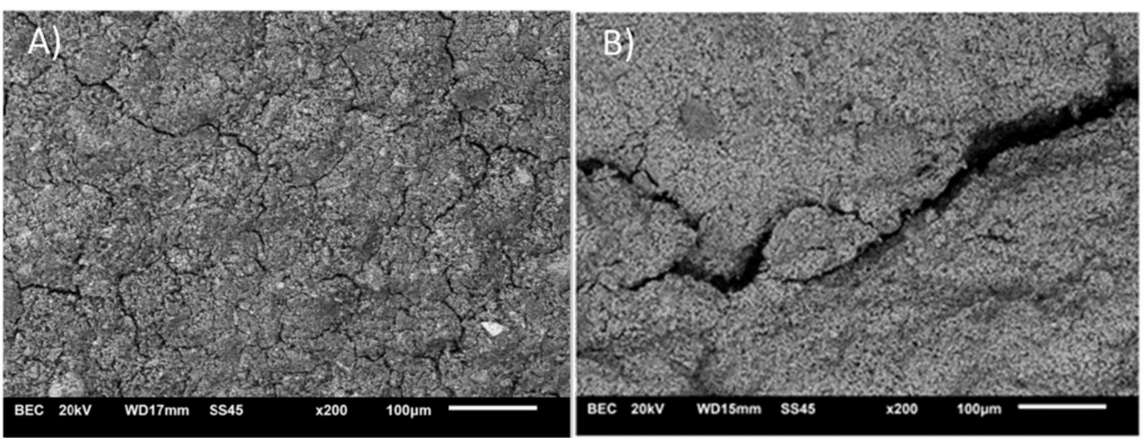

Figure 5. Comparison of microstructure before $\left((\mathbf{A}) 23^{\circ} \mathrm{C}\right)$ and after $\left((\mathbf{B}) 800^{\circ} \mathrm{C}\right)$ heating.

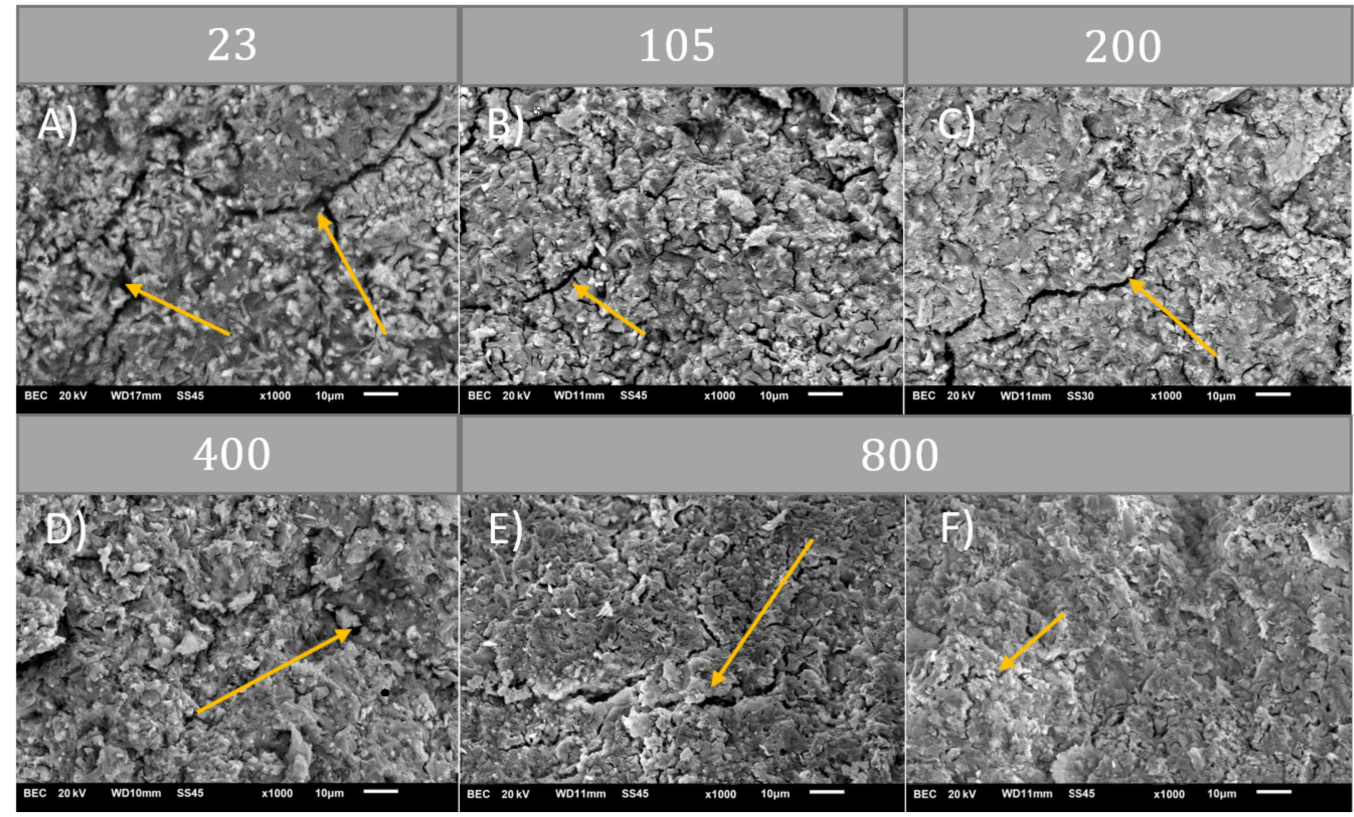

Figure 6. Comparission of microstructure $(\times 1000)$ after heating at different temperatures $\left((\mathrm{A}) 23^{\circ} \mathrm{C}\right)$; ((B) $\left.105^{\circ} \mathrm{C}\right) ;\left((\mathbf{C}) 200^{\circ} \mathrm{C}\right) ;\left((\mathbf{D}) 400^{\circ} \mathrm{C}\right) ;\left((\mathbf{E}) 800{ }^{\circ} \mathrm{C}\right) ;\left((\mathbf{F}) 800^{\circ} \mathrm{C}\right)$.

The performance of CSA pastes exposed to high temperature is connected to their microstructure. Research indicates that micro-cracking is presented in green state material. After exposure to $105^{\circ} \mathrm{C}$, the number of defects increased. Previous research showed that at $200{ }^{\circ} \mathrm{C}$ strength parameters decreased, which might be caused by increased micro-cracking shown in the present investigation. The structure of the material became more fine and "curlier". Pictures of structures obtained at $800{ }^{\circ} \mathrm{C}$ show a decreased amount of defects. 
Smaller defects probably were self-healed by a re-sintering process. Kaczmarczyk et. al [28] argue that silica with free lime and alkali particles present may create glassy phases below $900^{\circ} \mathrm{C}$. Nonetheless, some of the cracks become larger and might have contributed to the loss of load capacity.

Map-data show that silica was located near lime (Figures 7-9). These clusters of silica-lime were poor in alumina oxides content (Figures 7-9). Mentioned alumina oxides were usually present near sulfur oxides. Analyses indicate that magnesium oxide created clusters with silica oxides (Figures 7 and 9), where $\mathrm{MgO}$ may be the promoter of a re-sintering process with $\mathrm{SiO}_{2}$. Previous evidence shows $[29,30]$ that magnesium oxide has a positive influence on temperature decrease of the firing process of CSA cement. The presented data and discussion indicate that during high-temperature heating (above $600{ }^{\circ} \mathrm{C}$ ), the microstructure might be re-sintered. It needs to be highlighted that this creates space to modify the structure by extra materials to increase the temperature resistance of CSA paste.

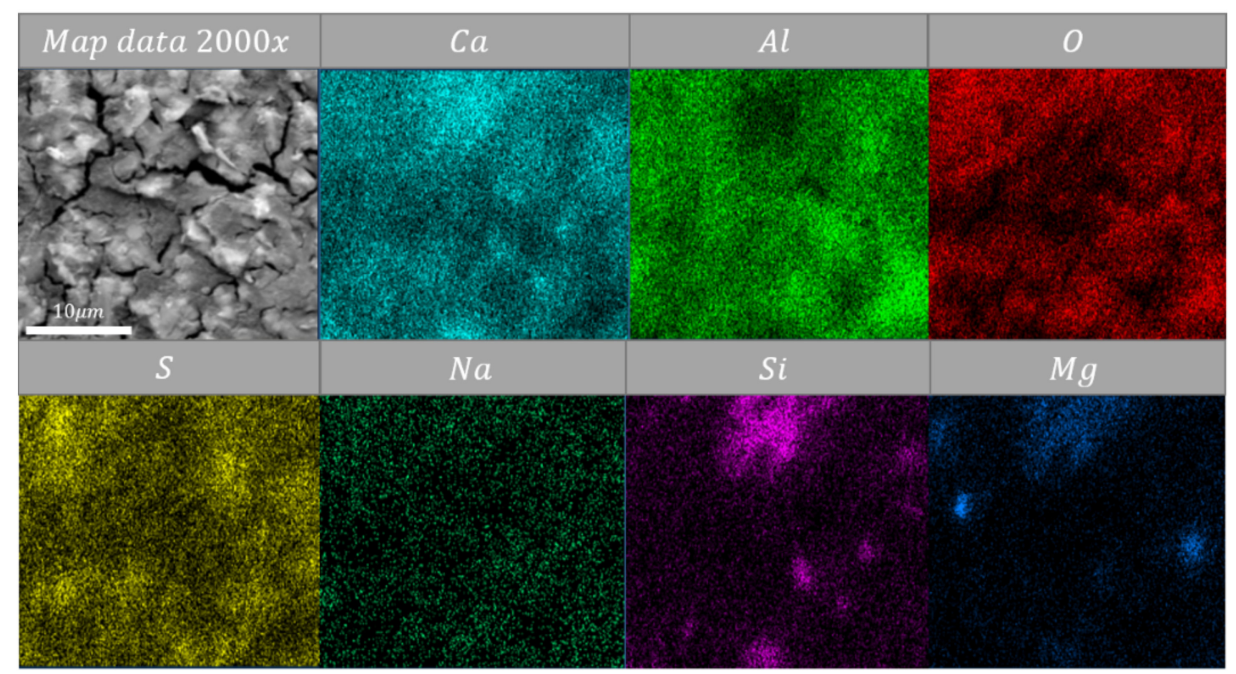

Figure 7. Energy-dispersive spectroscopy (EDS) map data of sample heated at $105^{\circ} \mathrm{C}$ Magnification: $\times 2000$.

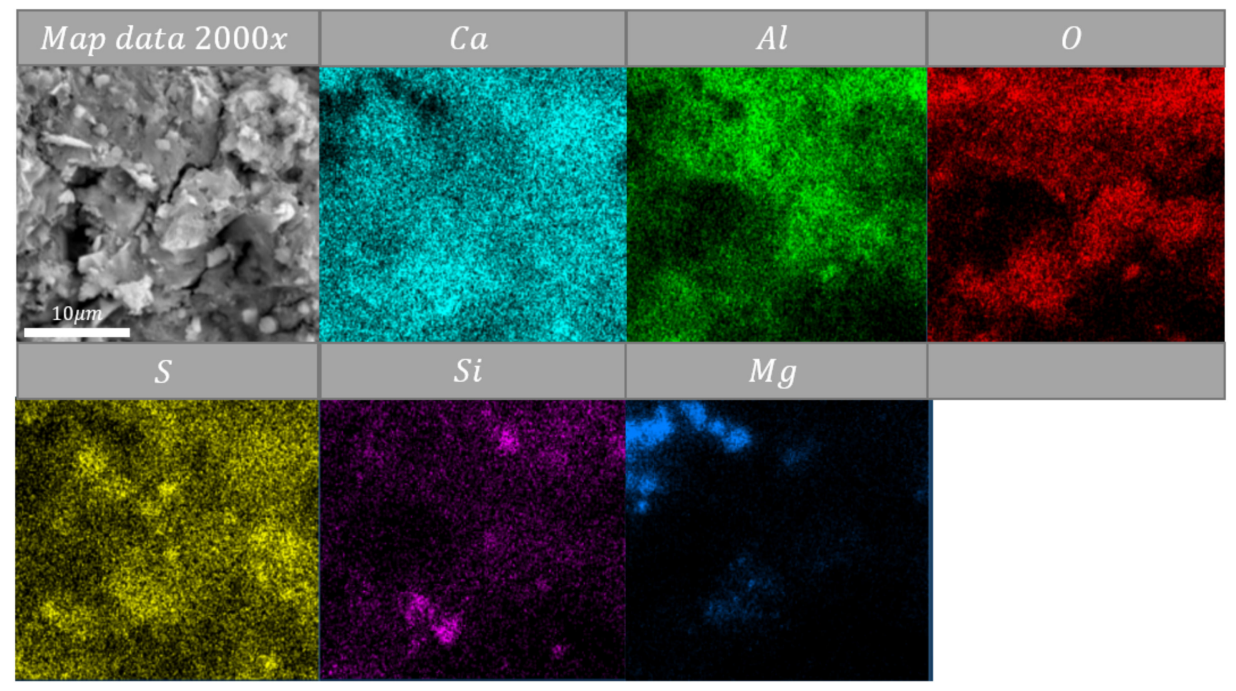

Figure 8. EDS map data of sample heated at $400{ }^{\circ} \mathrm{C}$, magnification: $\times 2000$. 


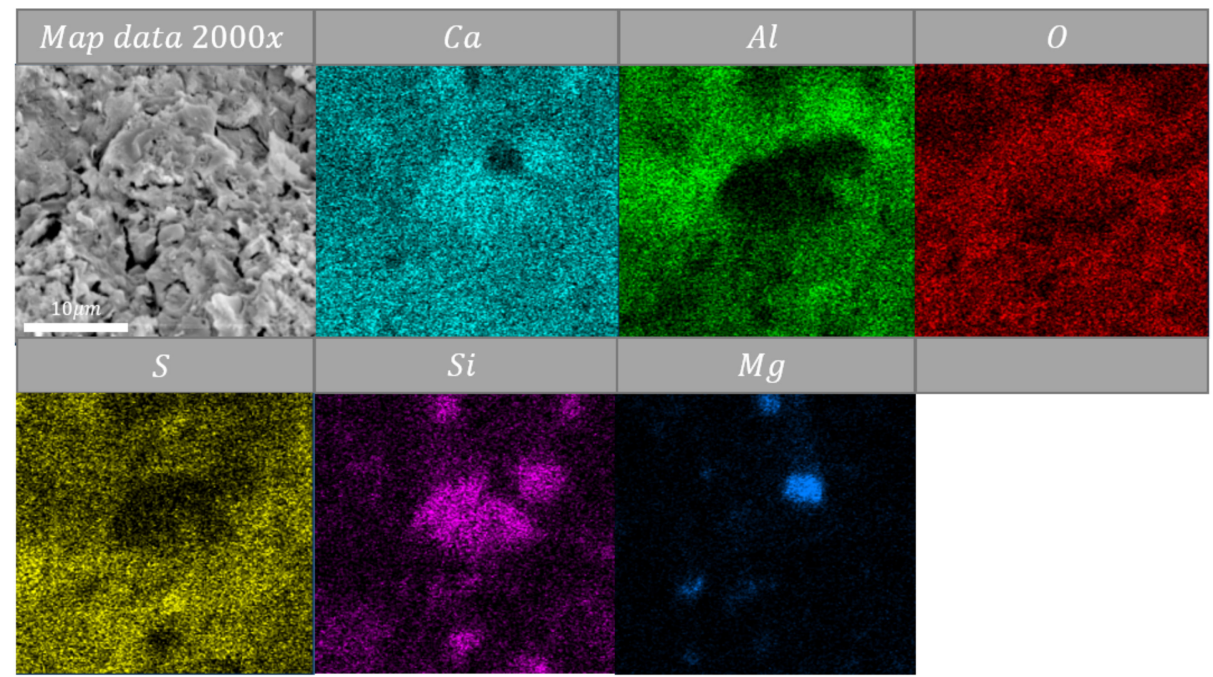

Figure 9. EDS map data of sample heated at $800^{\circ} \mathrm{C}$, magnification: $\times 2000$.

\section{Conclusions}

- Visual assessment might be used in general definition of the residual strength of material. CSA paste exposed to temperature lower than $600{ }^{\circ} \mathrm{C}$ did not change color significantly. The color was natural beige. Material exposed to $600{ }^{\circ} \mathrm{C}$ had a characteristic color, dark gray with black pieces. At $800^{\circ} \mathrm{C}$, the color changed to light gray. Between $600^{\circ} \mathrm{C}$ and $800{ }^{\circ} \mathrm{C}$, cracks were smaller than at $400{ }^{\circ} \mathrm{C}$.

- Based on measured weight of specimens at different temperature points the equation of density as a temperature function was specified, $\rho_{\mathrm{T}}(\mathrm{T})=\rho_{23}{ }^{\circ} \mathrm{C}+0.92 \mathrm{~T}$ with correlation coefficient $R^{2}=0.85$ and $\rho_{T}(T)=0.0014 T^{2}-2.2062 T+1919.6$ with correlation coefficient $R^{2}=0.94$. First, a linear equation might be used in a preliminary checking calculation. Second, a third order equation might be used with issues that demand more accurate calculations.

- The highest flexural strength collapse ( $12.1 \%$ of initial value) was observed at $200{ }^{\circ} \mathrm{C}$, which relates to dehydration of main phase ettringite.

- The CSA paste had residual strength over entire temperature range.

- Compressive strength decrease was significant $\left(24.4 \%\right.$ of initial value) above $300{ }^{\circ} \mathrm{C}$. Between $300^{\circ} \mathrm{C}$ and $600^{\circ} \mathrm{C}$ it was stable in the $15-10 \mathrm{MPa}$ range $(24.4-19.2 \%$ of starting value). Between $600{ }^{\circ} \mathrm{C}$ and $800{ }^{\circ} \mathrm{C}$ it was in the $10-8 \mathrm{MPa}$ range (15.5-13\% of green state).

- Microstructure and EDS investigations show that micro-cracks are present in the green state of the material. Propagation of defects was increased up to $400{ }^{\circ} \mathrm{C}$. Above that, between $600{ }^{\circ} \mathrm{C}$ and $800{ }^{\circ} \mathrm{C}$, number of cracks decreased. Nonetheless, defects that remained became thicker.

- Map-data indicate that free-lime clustered with silica. Magnesium oxide creates groups displacing other ingredients and is in close relation to $\mathrm{SiO}_{2}$. This might have to do with a two-component system $\mathrm{CaO}-\mathrm{SiO}_{2}$, where $\mathrm{MgO}$ might be a sintering promotor. As a result, some micro-cracks might disappear because of re-sintering of the cement particles during high-temperature heating. Sulfonate ingredients are present in close connection with aluminium oxide.

- Influence of high temperature on calcium sulfoaluminate-based materials should be continued.

Author Contributions: Conceptualization: K.A.S.; methodology: K.A.S.; formal analysis, K.A.S., S.M.; investigation: K.A.S., S.M.; data curation, K.A.S., S.M.; writing-original draft preparation, K.A.S.; writing-review and editing, Ł.K., J.S. and S.M.; visualization, K.A.S.; supervision, Ł.K., J.S. and M.S.; project administration, K.A.S. All authors have read and agreed to the published version of the manuscript. 
Funding: This research was co-funded by Hydro Building Systems Poland and the "Industrial Ph.D." program granted by the Ministry of Science and the Higher Education Republic of Poland.

Institutional Review Board Statement: Not applicable.

Informed Consent Statement: Not applicable.

Data Availability Statement: The data that support the findings of this study are available on request from the corresponding author.

Conflicts of Interest: The authors declare no conflict of interest.

\section{References}

1. Barcelo, L.; Kline, J.; Walenta, G.; Gartner, E. Cement and carbon emissions. Mater. Struct. 2014, 47, 1055-1065. [CrossRef]

2. Tambara, L.; Cheriaf, M.; Rocha, J.C.; Palomo, A.; Jimenez, A.M.F. Effect of alkalis content on calcium sulfoaluminate (CSA) cement hydration. Cem. Concr. Res. 2019, 128, 105953. [CrossRef]

3. Coppola, L.; Coffetti, D.; Crotti, E.; Gazzaniga, G.; Pastore, T. An Empathetic Added Sustainability Index (EASI) for cementitious based construction materials. J. Clean. Prod. 2019, 220, 475-482. [CrossRef]

4. ASTM. C 845: Standard Specification for Expansive Hydraulic Cement; ASTM International: West Conshohocken, PA, USA, 2012; Volume 4, pp. 1-3.

5. Winnefeld, F.; Ben Haha, M.; Lothenbach, B. Hydration mechanisms of calcium sulfoaluminate cements assessed by scanning electron microscopy and thermodynamic modelling. In Proceedings of the 13th International Congress on the Chemistry of Cement, Madrid, Spain, 3-8 July 2011; pp. 1-7.

6. Tur, W.; Król, M. Beton Ekspansywny; Arkady: Warsaw, Poland, 1999.

7. Batog, M.; Synowiec, K. Cement i spoiwa specjalne zawierające klinkier siarczanoglinianowy. Bud. Technol. Archit. 2017, 1, 59-64.

8. Hager, I. Behaviour of cement concrete at high temperature. Bull. Pol. Acad. Sci. Tech. Sci. 2013, 61, 145-154. [CrossRef]

9. Kodur, V.; Dwaikat, M.M.S.; Dwaikat, M.B. High-Temperature properties of concrete for fire resistance modeling of structures. ACI Mater. J. 2008, 105, 517-527.

10. Kodur, V.; Khaliq, W. Effect of Temperature on Thermal Properties of Different Types of High-Strength Concrete. J. Mater. Civ. Eng. 2011, 23, 793-801. [CrossRef]

11. Hager, I.; Tracz, T.; Choińska, M.; Mróz, K. Effect of cement type on the mechanical behavior and permeability of concrete subjected to high temperatures. Materials 2019, 12, 3021. [CrossRef] [PubMed]

12. Gawin, D.; Pesavento, F.; Schrefler, B.A. What physical phenomena can be neglected when modelling concrete at high temperature? A comparative study. Part 1: Physical phenomena and mathematical model. Int. J. Solids Struct. 2011, 48, 1927-1944. [CrossRef]

13. Gawin, D.; Schrefler, B.A. Thermo-hydro-mechanical analysis of partially saturated porous materials. Eng. Comput. 1996, 13, 113-143. [CrossRef]

14. Gawin, D.; Pesavento, F.; Schrefler, B.A. What physical phenomena can be neglected when modelling concrete at high temperature? A comparative study. Part 2: Comparison between models. Int. J. Solids Struct. 2011, 48, 1945-1961. [CrossRef]

15. Collier, N. Transition and Decomposition Temperatures of Cement Phases-A Collection of Thermal Analysis Data. Ceram. Silik. 2016, 60, 338-343. [CrossRef]

16. Kaufmann, J.; Winnefeld, F.; Lothenbach, B. Stability of ettringite in CSA cement at elevated temperatures. Adv. Cem. Res. 2016, 28, 251-261. [CrossRef]

17. Sodol, K.A.; Kaczmarek, Ł.; Szer, J. Fire-Temperature Influence on Portland and Calcium Sulfoaluminate Blend Composites. Materials 2020, 13, 5230. [CrossRef]

18. Bieda, W.; Laurecka, H. Masy, Betony i Prefabrykaty Ogniotrwałe; Śląsk: Katowice, Poland, 1981.

19. Zimka, R.; Hajto, D.; Marcinkiewicz, K. CSA Cements based on calcium sulfoaluminates. Builder 2016, 83, 15-17.

20. Winnefeld, F.K. Concrete produced with calcium sulfoaluminate cement-A potential system for energy and heat storage. In Proceedings of the First Middle East Conference on Smart Monitoring, Assessment and Rehabilitation of Civil Structures, Dubai, United Arab Emirates, 8-10 February 2011; pp. 1-9.

21. PN-B-04500: Zaprawy Budowlane-Badania cech Fizycznych i Wytrzymałościowych; Polish Standarization Comittee: Warszawa, Poland, 1985.

22. Lublóy, É. Heat resistance of portland cements. J. Therm. Anal. Calorim. 2018, 132, 1449-1457. [CrossRef]

23. Rafi, M.M.; Aziz, T.; Lodi, S.H. Mechanical properties of low-strength concrete at exposure to elevated temperatures. J. Struct. Fire Eng. 2017, 8, 418-439. [CrossRef]

24. Lim, S. Effects of Elevated Temperature Exposure on Cement-Based Composite Materials; University of Illinois at Urbana-Champaign: Champaign, IL, USA, 2015.

25. Kizilkanat, A.B.; Yüzer, N.; Kabay, N. Thermo-physical properties of concrete exposed to high temperature. Constr. Build. Mater. 2013, 45, 157-161. [CrossRef]

26. Pachta, V.; Tsardaka, E.-C.; Stefanidou, M. The role of flame retardants in cement mortars exposed at elevated temperatures. Constr. Build. Mater. 2021, 273, 122029. [CrossRef] 
27. Freskakis, G.N.; Burrow, C.; Debbas, E.B. Strength Properties of Concrete at Elevated Temperatures; Civil Engineering Nuclear Power; Burns and Roe, Inc.: Oradell, NJ, USA, 1979; Volume 1, p. 30.

28. Kaczmarczyk, K.; Partyka, J. Physicochemical properties of glass-ceramic materials from the $\mathrm{SiO}_{2}-\mathrm{Al}_{2} \mathrm{O}_{3}-\mathrm{Na}_{2} \mathrm{O}-\mathrm{K}_{2} \mathrm{O}-\mathrm{CaO}-\mathrm{MgO}$ system with barium oxide addition. Szkło Ceram. 2018, 69, 6-10.

29. Liu, X.; Li, Y.; Zhang, N. Influence of $\mathrm{MgO}$ on the formation of $\mathrm{Ca}_{3} \mathrm{SiO}_{5}$ and $3 \mathrm{CaO}_{3} \cdot \mathrm{Al}_{2} \mathrm{O}_{3} \cdot \mathrm{CaSO}_{4} \mathrm{minerals}$ in alitesulphoaluminate cement. Cem. Concr. Res. 2002, 32, 1125-1129. [CrossRef]

30. Wang, Y.; Liu, S.; Xuan, D.; Guan, X.; Zhang, H. Improving the Mechanical Properties of Sulfoaluminate Cement-Based Grouting Material by Incorporating Limestone Powder for a Double Fluid System. Materials 2020, 13, 4854. [CrossRef] [PubMed] 